\title{
Research on the Construction of Enterprise Performance Evaluation Index System Based on Value Creation
}

\author{
Yurong Gao \\ Shandong Women's University \\ Jinan, China
}

\begin{abstract}
The management of the enterprise is ultimately the management of the value creation of the enterprise. The research on the enterprise performance evaluation model based on the value creation can help the enterprise to enhance the competitive advantage. This paper studies performance evaluation index from the perspective of value creation performance and value creation ability, and tries to construct an enterprise performance evaluation index system based on value creation in order to better improve the management abilities of the enterprise and achieve the sustainable development of the enterprise.
\end{abstract}

Keywords—value creation; performance evaluation

\section{INTRODUCTION}

With the new opportunities and challenges that economic globalization has brought to all countries, Chinese enterprises are facing severe challenges in their ongoing operations and value creation. The survival and development of enterprises are also facing tremendous pressure and challenges. To achieve lasting and stable development, enterprises should combine value creation with performance evaluation, and be guided by value creation, establish a scientific, rational and operational evaluation system of listed enterprises' operating performance, and promote investors' continuous attention to enterprise performance and in-depth exploration of value creation abilities so as to achieve the goal of improving the management of the enterprise and achieving the sustainable development of the enterprise.

\section{ANALYSIS ON THE DRIVING FACTORS OF ENTERPRISE VALUe CREATION}

The fundamental purpose of an enterprise's performance evaluation is to evaluate the size of the enterprise's value creation and its ability to create value. In measuring the value creation performance of enterprises, many enterprises use the theory of value assessment, which is the sum of the present value of discounted economic benefits created during the future operating period using the discount rate that is appropriate to the risk level of the enterprise. Therefore, the value creation of a enterprise must first have profitability in order to create high returns. At the same time, this kind of income should have continuity and growth, and it is necessary to pay attention to the enterprise's ability to grow in performance evaluation. In order to survive for a long time, an enterprise should also have good solvency. The size of solvency reflects the degree of financial risk of enterprises, but also affects the cost of capital and the value of enterprises. Therefore, enterprise value creation performance should be evaluated in terms of profitability, growth ability and solvency.

The value of an enterprise's value-creating ability depends on the key factors that can drive the value creation of the enterprise. Since twenty-first Century, enterprise value management activities have shifted to customer value management, that is, through the creation of value for customers to gain the value of the enterprise's value-added. Customer value can be measured by customer value added (customer perception utility-price). In order to increase the added value of customers, enterprises must have operational abilities, research and development abilities, and marketing abilities, which are key index to reflect the value creation ability of enterprises in the enterprise performance evaluation system.

\section{The Construction Principles of EnTERPRISE Performance EVAluation IndeX System}

\section{A. Principle of Objectivity}

In order to guide the enterprise to make constant value creation, when evaluating the performance of an enterprise, it must be objective and impartial, so that we can reasonably design the index system and scientifically select the evaluation method. At the same time, a unified evaluation standard and standard operation procedures should be formulated. When conducting evaluations, it should be based on verifiable facts and data as the basis for evaluation so that performance evaluation can be objective and fair. In addition, experts from third parties are also required to participate in the judgement of their independent positions and professional abilities, and scientifically and reasonably measure their performance so as to ensure that performance evaluation is not affected by human factors to avoid deviations due to subjectivity, prejudice, and incompetence.

\section{B. Principle of Pluralism}

When constructing an enterprise performance evaluation index system, a diversified evaluation index system should be established, which not only measures the value creation of the enterprise, but also reflects the level of the enterprise's value 
creation ability. The selection of index should emphasize the combination of financial index and non-financial index. Because many non-financial index of the enterprise are difficult to calculate and measure, the data of financial index is relatively easy to obtain, objective and reliable. Therefore, in the design of the evaluation index system, financial index should be the main ones, and non-financial index should be used for assessment as much as possible on the basis of measurement and availability.

\section{Principle of Applicability}

In order to ensure the effectiveness of the evaluation, the applicability principle should be fully considered when evaluating the index. First, the number of index should be simple and straightforward. The index is the refinement and summarization of the original information. The index should not be too cumbersome, and the number should not be too much, so as to avoid overestimating, failing to grasp the essence of the evaluation image and affecting the accuracy of evaluation. At the same time, the refinement of index can reduce the time and cost of evaluation, making evaluation activities easier to operate. Second, the data is easy to collect. Index data set should be relatively easy to obtain, so that the performance evaluation operation is more convenient. The last one is intelligibility. The index that are relatively mature and familiar to everyone should be selected so as to facilitate the understanding of all parties involved in the evaluation work and ensure the accuracy of the evaluation results.

\section{Principle of Cost-effectiveness}

The cost-effectiveness principle is an issue that must be considered before the formulation and implementation of any enterprise system and the performance evaluation system is of no exception. In the process of designing an enterprise performance evaluation system based on value creation, it is necessary to consider the cost and benefit of implementation. If some evaluation index are important, but the cost of obtaining the data of the index is greater than the benefit or cost it can bring, the index should generally be discarded or other similar but lower cost index should be used instead.

\section{Enterprise Performance Evaluation Index System BASED ON VALUE CREATION}

As mentioned above, performance evaluation of an enterprise based on value creation should be conducted in terms of value creation performance and value creation capability. Value creation performance index should mainly include the enterprise's profitability, solvency ability and growth ability. The value creation ability index should include the enterprise's operational ability, research and development ability, and marketing ability [4].

\section{A. Value Creation Performance Index Selection}

\section{1) Profitability Index Selection}

In practice, the basic index that reflect the enterprise's profitability are EVA, return on equity and net profit margin. Among them, EVA is the residual income after adjusting the post-tax operating income minus the total cost of capital, and can accurately measure whether the enterprise realizes revenue in the sense of economic profit; return on equity is the profit after tax profit divided by the average stockholders' equity, and it measures the level of earnings of managers using their own capital. The net profit margin is the net profit divided by the sales revenue [1], the analysis of which can prompt enterprises to expand the market while paying attention to increase the proportion of high-quality customer base and operational management abilities, and reduce the management risks caused by scale expansion.

\section{2) Solvency Index Selection}

Solvency abilities reflect the ability of enterprises to repay short-term and long-term debt. In practice, the solvency abilities selected by more enterprise are current ratio, assetliability ratio and cash ratio. Among them, the current ratio is the current assets divided by the current liabilities. When using this index to measure the abilities and financial liquidity status of the enterprise's current liabilities, the capital structure and industry characteristics of the enterprise must also be considered; asset-liability ratio is the total debt divided by the total assets, which is used to measure the level of enterprise financial risk and the degree of protection of creditors' rights; the cash ratio is the net operating cash flow divided by the sales revenue, reflecting the marketing policy of enterprise.

\section{3) Growth Ability Index Selection}

Growth abilities can predict enterprise development speed and trends. The index system selects the total asset growth rate, operating cash flow ratio, and operating profit growth rate as abilities index. Among them, the total asset growth rate is the total asset growth divided by the total amount of assets at the beginning of the period and measures the expansion rate of enterprise scale; the operating cash flow ratio is calculated by dividing the net operating cash flow by the total current liabilities to measure the abilities of using operating cash to repay current liabilities; operating profit growth rate reflects the efficiency of the company's growth.

\section{B. Value Creation Ability Index}

\section{1) Operational Performance Ability Index}

The basic indexes that reflect enterprise operations abilities include rate of capacity utilization, turnover ratio of receivable, cash operating index and turnover of total capital. Among them, rate of capacity utilization is the actual output of enterprise divided by the total production capacity of the production equipment for measuring how much the actual productivity of the enterprise is in production. The turnover ratio of receivable is the sales revenue divided by the average total receivables. The assessment of the speed and efficiency of the realization of the receivables can reflect whether the enterprise has a large amount of sluggish receivables so as to adjust the credit policy and sales strategy; cash operating index is the net operating cash flow minus the net increase in operating assets divided by the net operating cash flow. Turnover of total capital refers to the ratio of business net income to total average assets for a certain period of time. It is an important index to comprehensively evaluate the quality of the entire enterprise's assets and the efficiency of its use. 


\section{2) R\&D Ability Index}

The $R \& D$ abilities of enterprise reflect the innovation abilities of an enterprise, providing momentum for the continued value creation of listed companies. R\&D abilities are evaluated in terms of $R \& D$ input intensity, $R \& D$ output capacity and assessed by selecting $R \& D$ expenditure as a percentage of sales revenue, new product sales revenue as a percentage of total sales revenue, etc. The higher the ratio of R\&D expenditures to sales revenues, the more importance enterprises place on $R \& D$ activities. The new product sales share belongs to the enterprise profitability index, which reflects the effective improvement of new product sales to the enterprise, reflects the output capacity of $R \& D$, and is a sign of enterprise efficiency improvement and technological innovation. [2]

\section{3) Marketing Ability Index}

In evaluating enterprise marketing abilities, customer satisfaction, market share, and customer profitability are selected as the evaluation index. Enterprise should improve product quality, understand customer needs, improve aftersales service quality, make customers satisfied with product quality and service quality, continuously improve customer satisfaction, and actively develop new customers while maintaining good customer relationship with old customers, which will inevitably increase the market share of enterprise [3]. As customer satisfaction and market share increases, more high-quality customers will be attracted, which will increase customer profitability and generate more profits for enterprises, thereby creating more value.

In summary, the following table shows the details:

TABLE I. THE ENTERPRISE PERFORMANCE EVALUATION INDEX SYSTEM BASED ON VALUE CREATION

\begin{tabular}{|c|c|c|}
\hline Evaluation angle & Index type & Evaluation index \\
\hline \multirow{9}{*}{$\begin{array}{l}\text { Value } \\
\text { performance }\end{array}$} & \multirow{3}{*}{ Profitability ability index } & EVA \\
\hline & & Return on equity \\
\hline & & Net profit margin \\
\hline & \multirow{3}{*}{ Solvency index } & Current ratio \\
\hline & & Asset-liability ratio \\
\hline & & Cash ratio \\
\hline & \multirow{3}{*}{ Growth ability index } & Total asset growth rate \\
\hline & & Operating Cash Flow Ratio \\
\hline & & Operating profit growth rate \\
\hline \multirow{9}{*}{ Value creation ability } & \multirow{4}{*}{ Operational ability index } & Rate of capacity utilization \\
\hline & & Turnover ratio of receivable \\
\hline & & Cash operating index \\
\hline & & Turnover of total capital \\
\hline & \multirow{2}{*}{$\mathrm{R} \& \mathrm{D}$ ability index } & $\begin{array}{l}\text { R\&D expenditure as a percentage of } \\
\text { sales revenue }\end{array}$ \\
\hline & & $\begin{array}{l}\text { New product sales revenue as a } \\
\text { percentage of total sales revenue }\end{array}$ \\
\hline & \multirow{3}{*}{ Marketing ability index } & Customer satisfaction \\
\hline & & Market share \\
\hline & & Customer profit rate \\
\hline
\end{tabular}

In short, the enterprise constructs a performance evaluation index system based on value creation, and conducts scientific and rational evaluation of the enterprise's performance from both the value creation performance and the value creation ability, and guides the enterprises to continuously increase value creation activities to continuously improve the management level of the enterprise.

\section{REFERENCES}

[1] Sun Mingyue, Yu Minghua. Performance Evaluation System Based on Combination of EVA and BSC[J]. CHIEF FINANCIAL, 2018, 1

[2] Li Mengyang, Guo Chaoyang. Application of Non-financial index in Enterprise Performance Evaluation System [J]. Finance and Accounting, 2017, 6

[3] Zhu Bo, Li Yu. Construction and Implementation of Enterprise Management Accounting Application System Based on Value Creation[J].Accounting Research, 2017,6

[4] Bie Xiaozhu, Hou Guangming. Analysis Framework of Enterprise Value Creation ability [J]. Commercial Age, 2005, 10 